\title{
The Spontaneous Haemolytic Activity of Catla catla Blood Serum Represents the Characteristics Features
}

\author{
Pushpa Choudhary ${ }^{1,2 *}$ and M. Makesh ${ }^{1,3}$ \\ ${ }^{I}$ Fish Health Management Division, ICAR-Central Institute Freshwater Aquaculture, \\ Bhubaneswar, 751002, Odisha, India \\ ${ }^{2}$ Aquatic Environment and Health Management Division, Central Institute of Fisheries \\ Education, Versova, Mumbai 400061, India \\ ${ }^{3}$ Fin Fish Culture Division, ICAR-Central Institute of Brackishwater Aquaculture, Chennai \\ 600028 , India \\ *Corresponding author
}

\section{A B S T R A C T}

In this study an attempt was taken to determine the spontaneous haemolytic activity $50 \%$ (SH50\%) of healthy catla (Catla catla) fingerlings serum with respect to its characteristics

Keywords

Complement,

Spontaneous haemolytic

activity, Heat sensitivity,

Zymosan, A. hydrophila;

Labeorohita

Article Info

Accepted:

15 July 2019

Available Online:

10 August 2019 features such as optimal temperature, ability for lysing red blood cells (RBCs) from various animals, heat sensitivity, storage temperature and effect of different agents like EDTA, EGTA. In addition to these, complement binding factors such as Zymosan, Lipopolysacharide were also tested for $\mathrm{SH} 50 \%$ activity. Furthermore, the effect of bacterial culture was also determined on $\mathrm{SH} 50 \%$ activity of catla sera. The most advantageous temperature for rabbit RBCs lysis was determined as $20^{\circ} \mathrm{C}$ for catla serum. The normal catla serum was found to be heat sensitive and it was obtained as more than 60 ${ }^{\circ} \mathrm{C}$. The haemolytic activity of catla sera showed reasonable activity after short term storage at $-20{ }^{\circ} \mathrm{C}$ and good activity after six months storage at $-80{ }^{\circ} \mathrm{C}$. Furthermore, the chemical effects of ethylene glycol-bis( $\beta$-aminoethyl ether)- $N, N, N^{\prime}, N^{\prime}$-tetraacetic acid (EGTA) and Ethylenediaminetetra acetic acid (EDTA) on SH $50 \%$ activity was found to be opposite in action, inhibition of SH $50 \%$ was obtained with EGTA whereas enhanced SH 50\% activity with EDTA. Also, the inhibitory effects of Zymosan, bacterial LPS and Aeromonas hydrophila culture were detected for haemolytic activity of catla sera.

\section{Introduction}

The non-specific immune system acts against any pathogenic organisms immediately after invasion, usually it uses pattern recognition receptor and eliminates pathogens by acting on pathogen associated molecular patterns which is conserved among microbes (Ellis,
2001; Magnadottir, 2006; Whyte, 2007; Uribe et al., 2011). For preventing recurrent infection and homeostasis of animals specific immune system is highly desirable. In invertebrates the innate immune system is the sole source of defense for survival in adversely changing aquatic environments (Akira et al., 2006). The innate or non-specific 
immune system primarily helps combating microbial infection in fish and it consists of several non-specific humoral defense mechanisms to cope up for their lesser specific immune response (Alexander and Ingram, 1992). The natural or spontaneous haemolytic activity of normal sera for untreated RBC is believed to be the function of alternative pathway of complement system, which has been evolved first in fish (Farries and Atkinson, 1991). Alternative complement pathway (ACP) of complement system is one of the efficient humoral defense mechanism and capable of bringing protection from a number of microorganisms such as bacteria, fungi, viruses (Miller-Eberhard, 1988). Fish the lower vertebrates possess more ACP titer and get activated at lower optimal temperature $\left(10-17^{\circ} \mathrm{C}\right)$ than mammals, due to which fish complement becomes the most effective immune mechanism (Sunyer and Lambris, 1998). Like mammalian complement system, complement system in fish is also activated through three pathways viz. classical pathway, alternative complement pathway and the lectin pathway (Sunyer and Lambris, 1998; Holland and Lambris, 2002). These three complement pathways merge to form lytic pathway which is capable of direct lysis of invading pathogens. Like higher vertebrates the complement system of fish also comprising of diverse proteins and complement component (C3) is present in all complement pathways, which has been studied extensively from several teleost species (Nakao et al., 2003). The molecular characterization of complement component (C3) of L. rohita has also been studied recently by (Pushpa et al., 2014).

The natural haemolytic activity being referred as an indicator of the effects of innate or foreign factors on the disease resistance \& immune system of fish. These factors (internal and external) are genetic traits (Salte et al., 1993), seasonal factors (Magnadottir, 2000), the environmental temperature (Nikoskelainen et al., 2004), pollution (Sakai, 1999), handling, crowding stress (Ortuno et al., 2001b), herbal medicine (Wu et al., 2013), diets and food additives (Ortuno et al., 2001a), immunostimulants and probiotics (Guardiola et al., 2016) also the effects of disease and vaccination (Anderson, 1992), etc. There is unavailability of quality information on spontaneous haemolytic activity of fish, particularly about catla (Catlacatla) which is one of the important candidate species of freshwater carp, especially in India. $\mathrm{SH}$ activity of seabass and halibut in normal sera was investigated recently by Lange and Magnadottir, 2003. The present study was undertaken to examine the spontaneous haemolytic activity of catla (Catlacatla) normal sera and to determine the impact of complement activation caused by haemolytic activity. Having a good knowledge and discernment of the defense mechanism of the species would provide relevant information on the potential of immune response and it could also be an important means for checking the health status of the fish under aquaculture practices.

\section{Materials and Methods}

\section{The fish}

Rohu (Labeorohita), weighing $50 \pm 5$ g, was transported from the local fish farm, Mumbai, India in oxygenated plastic bags. The fish were acclimatized in a cemented circular 500 $\mathrm{L}$ capacity tank for 15 days with aeration at ambient water temperature, $28 \pm 2{ }^{\circ} \mathrm{C}$. Water exchange in the fish tank was done at regular interval of two days and fishes were fed with commercially available feed two times a day.

\section{Blood collection and serum separation}

First 20-25 rohu were anaesthetized by immersing them in two liter of water containing $100 \mu \mathrm{l}$ per liter clove oil (Himedia, 
India). Post that blood was drawn using disposable $2 \mathrm{ml}$ syringe from the caudal peduncle of the fish and was taken in the eppendorf tube, kept at tilt position for clotting for $20 \mathrm{~min}$ at room temperature and then incubated for 4 hour at $4{ }^{\circ} \mathrm{C}$. For separation of serum from blood, centrifugation was carried out at $1500 \times \mathrm{g}$ for $10 \mathrm{~min}$ at $4{ }^{\circ} \mathrm{C}$ (Hareus, USA). Serum was collected in sterile eppendorf tubes and stored in aliquots at $-80^{\circ}$ $\mathrm{C}$ for further experiments. Serum samples from eight different fish was drawn and spontaneous hemolytic activity determined for studying the individual variation among the fish serum with respect to the ability to lyse rabbit RBCs.

\section{Red blood cells (RBCs) Preparation}

RBCs collection was done from different donor animals (sheep, goat, rabbit, chicken and Pangasius sp.). Alsevers anticoagulant solution (Sigma, USA) and the collected RBCs taken in new tube $(1: 1, \mathrm{v} / \mathrm{v}$ ratio) and mixed together. The above solution was washed using normal saline $(0.85 \% \mathrm{NaCl}) 2-3$ times. $100 \mu \mathrm{l}$ of above RBCs was diluted in $3.4 \mathrm{ml}$ of distilled water and optical density of resulting solution was read at $414 \mathrm{~nm}$ in ELISA plate reader (Biorad, USA). A $1 \%$ suspension of RBCs is equivalent to optical density value of 0.74 so the RBC dilution was adjusted to obtain this reading. The resulting solution was mixed in veronal buffer saline (GVB) @ 1:1, v/v for getting $0.5 \%$ solution for carrying out haemolytic assay.

\section{The spontaneous haemolytic (SH) assay}

The spontaneous haemolytic activity of rohu sera was estimated by using the method described by Lange et al., (2001) with some modifications. Briefly, RBCs from sheep, goat, rabbit, chicken and Pangasius fish were used as the target for determining spontaneous haemolytic activity of rohu sera. GVB (Lonza,
Switzerland) acted as reaction buffer which contained $10 \mathrm{mM}$ barbital, and $145 \mathrm{mM} \mathrm{NaCl}$ and $0.1 \%$ gelatin, $\mathrm{pH} 7.3 .2 \mathrm{ml}$ microcentrifuge tubes (Tarsons, India) was taken for carrying out the test. $100 \mu 1$ of $0.5 \%$ of respective RBC were added in all tubes containing two fold dilutions of rohu serain GVB followed by incubation at room temperature for $1 \mathrm{~h}$ with occasional shaking. GVB replaced the serum (0\% lysis) acted as negative control while distilled water replaced the serum $(100 \%$ lysis) for positive control. Centrifugation of the incubated samples were carried out at 750 $\mathrm{x} \mathrm{g}$ for $10 \mathrm{~min}$, and $125 \mu \mathrm{l}$ of the supernatant was collected from each tube and transferred to a non-adsorbent flat bottom microtiter plate (Nunc, Denmark) and the absorbance read at $405 \mathrm{~nm}$. Assay was carried out in triplicates for each dilution. A graph of OD values vs. serum dilution was drawn and the $\mathrm{SH} 50 \%$, i.e., the serum dilution that gave $50 \%$ lysis was calculated. The $50 \%$ lysis point ( $\mathrm{SH} 50 \%$ ) was calculated by linear regression of each serum sample and expressed as the log dilution.

\section{Sensitivity of rohu serum to mammalian, avian and fish RBCs}

Spontaneous haemolytic assay were done to study the sensitivity of rohu serum to these target cells and for this purpose RBCs from donor animals such as sheep, goat, rabbit, chicken and Pangasius fish and these acted as target cells. However, all further $\mathrm{SH}$ assays were performed with sheep $\mathrm{RBC}$ at room temperature $\left(28-30{ }^{\circ} \mathrm{C}\right)$. Eight individual fish sera were evaluated to find the difference of spontaneous haemolytic activity.

\section{Estimation of optimum assay temperature for $\mathrm{SH50 \%}$}

For estimating the optimum assay temperature for $\mathrm{SH} 50 \%$ with sheep RBCs, different incubation temperatures viz. $10^{\circ} \mathrm{C}, 20^{\circ} \mathrm{C}$ and 
$30^{\circ} \mathrm{C}$ were selected for carrying out the SH 50 $\%$ assay.

\section{Heat sensitivity test}

The heat sensitivity of the complement factors in rohu sera was determined by incubating them at $18,27,45,56$ and $65^{\circ} \mathrm{C}$ for $30 \mathrm{~min}$ and the SH $50 \%$ assay was carried out as described earlier.

\section{The effects of EGTA and EDTA}

The effects of EGTA and EDTA was estimated by supplementing GVB with $1 \mathrm{mM}$ EGTA or $0.5 \mathrm{mM}-5 \mathrm{mM}$ EDTA and the SH 50 $\%$ assay was carried out same way as earlier.

Sensitivity of rohu sera with Aeromonashydrophila culture

The young culture of Aeromonas hydrophila (ATCC7966) which was grown overnight at $30^{\circ} \mathrm{C}$ in nutrient broth and equal volume of culture was incubated with rohu serum for 30 min and SH activity of serum was tested.

\section{The effects of complement binding factors}

Before doing the test, incubation of rohusera were done at room temperature for 30-60 min with zymosan and lipopolysaccharide. Fresh serum, which is used for comparison, was incubated under the similar condition in which the GV buffer was replaced with different agents.

\section{Treatment of sera with zymosan}

The protocol followed by the method described by Lange and Magnadottir, 2003. Briefly, $100 \mathrm{mg}$ of zymosan (Sigma) was weighted and centrifuged at $1200 \mathrm{x}$ g for 5 min for washing two times in 1-2 ml GVB. The pellet obtained was resuspended in $120 \mu 1$ of serum and1:5 dilutionsin GVB was made and then it was incubated for $30 \mathrm{~min}$ at room temperature $\left(28{ }^{\circ} \mathrm{C}\right)$. Once the incubation period is over, the supernatant collected for testing the $\mathrm{SH}$ activity.

\section{LPS (Lipo-polysaccharide)}

LPS, from E. coli (Sigma, USA) was used at a concentration of $5 \mathrm{mg} \mathrm{ml}^{-1}$. To make the serum $1 / 5$ dilution, $24 \mu \mathrm{l}$ of undiluted rohu serum was added to $50 \mu \mathrm{l}$ of LPS $(250 \mu \mathrm{g})$ and $46 \mu \mathrm{l}$ GVB and the resulting solution incubated for one hour at room temperature prior to carrying out the SH assay.

\section{Evaluation of the effect of storage on SH activity}

Rohu sera was pooled from 10 individual rohu fish and one aliquot was stored at $4{ }^{\circ} \mathrm{C}$, and the SH activity was tested after 1 week. Two sera aliquot were stored at $-80^{\circ} \mathrm{C}$ and SH activity was tested after 3 weeks and 5 months of storage. One sera aliquot was kept at $-20^{\circ} \mathrm{C}$ and $\mathrm{SH}$ activity was tested after 1 year of storage.

\section{Statistical analysis}

Statistical analysis of the results was done with the help of one-way analysis of variance (ANOVA) and paired student's t-test. $\mathrm{P}<0.05$ was set as the critical value of significance. SPSS ver. 16 software was used for the statistical analysis.

\section{Results and Discussion}

\section{The assay temperature}

For incubation of the serum samples, the three different incubation temperatures were used and the optimum temperature was obtained as $20^{\circ} \mathrm{C}$ for carrying out the spontaneous haemolytic activity. Maximum SH activity of rohu serum was found at this temperature. 
Since there was a little difference between $\mathrm{SH}$ $50 \%$ of rohu serum at $20{ }^{\circ} \mathrm{C}$ and $30{ }^{\circ} \mathrm{C}$. So, room temperature approx. $28{ }^{\circ} \mathrm{C}$ was used for finding SH activity for further experiments (Fig. 1).

\section{Red blood cell donors}

Among the tested target RBCs of different donor animals, the spontaneous haemolytic activity of the rohu sera showed variation to these RBCs (Fig. 2). Rohu sera gave highest mean SH $50 \%$ activity with rabbit RBCs followed by this with goat and chicken RBCs while lowest with Pangasius fish RBCs and also it has been found that there was variation in the spontaneous haemolytic activity among the eight individual rohufish sera tested (Fig. $3)$.

\section{Heat sensitivity of rohu sera}

The heat sensitivity of rohu sera upon incubation at different inactivation temperatures is shown in figure 4. Rohu sera showed reduced mean $\mathrm{SH} 50 \%$ activity at higher inactivation temperatures i.e., the trend of SH $50 \%$ reduction was obtained as $65^{\circ} \mathrm{C}>$ $56{ }^{\circ} \mathrm{C}>45^{\circ} \mathrm{C}>22^{\circ} \mathrm{C}>18^{\circ} \mathrm{C}$.

The highest reduction in SH $50 \%$ activity was more than $90 \%$ at $65{ }^{\circ} \mathrm{C}$ and lowest at $18{ }^{\circ} \mathrm{C}$ approx. $13 \%$ reduction.

\section{The effect of EGTA, EDTA}

The addition of EGTA in the buffer has resulted in inhibition of mean SH $50 \%$ activity of rohu sera while EDTA addition in the buffer enhanced the mean SH $50 \%$ activity as shown in figure 4. The EDTA showed highest mean SH $50 \%$ activity at 1 $\mathrm{mM}$ and least at $5 \mathrm{mM}$ concentrations of EDTA (Table 1, Fig. 5). There was about 40 $\%$ from 94 to 56 reduction in SH $50 \%$ activity when assay was done at $1 \mathrm{mM}$ EGTA supplemented GVB (Table.1).
The effects of some complement binding factors on the SH activity of rohu sera

SH $50 \%$ activity of rohu sera was found to be reduced upon Zymosan and LPS treatment as compare to control (Fig. 6). Zymosan treatment of rohu has resulted in maximum reduction in $\mathrm{SH} 50 \%$ activity of rohu sera whereas LPS to a lesser extent. The SH $50 \%$ activity decreased to approximately $90 \%$ when the test was done with zymosan. LPS reduced SH 50\% activity by approximately 40 $\%$.

The effect of Aeromonashydrophila culture on SH activity of rohu sera

Rohu sera after the incubation with young $A$. Hydrophila culture showed depletion in the mean SH $50 \%$ activity as compare to control (Fig. 6). The reduction of SH $50 \%$ activity was obtained as more than $50 \%$ as compared to control.

\section{The effect of storage on the SH activity of the sera}

The effect of storage on the SH activity of the rohu sera is shown in figure 7 . The storage of sera for 1 year at deep freezer $\left(-20{ }^{\circ} \mathrm{C}\right)$ has resulted in reduction in the $\mathrm{SH} 50 \%$ activity, more than $90 \%$ reduction in SH 50\% activity while storage at $-80{ }^{\circ} \mathrm{C}$ for 3 weeks and 5 months showed slightly less reduction in $\mathrm{SH}$ $50 \%$ activity than the control values. The storage at $4{ }^{\circ} \mathrm{C}$ for 1 week, reduced the SH 50 $\%$ activity to a certain extent than control.

From the earlier studies it has been established that the alternative complement pathway of complement system, one of the important innate immune components is usually responsible for the spontaneous or natural haemolytic activity of normal fish blood serum (Holland and Lambris, 2002; Nikoskelainen et al., 2002; Boesen et al., 1999; Fock et al., 2001). In the present study, 
the spontaneous haemolytic activity of normal serum was determined with relation to the different RBCs donors, different storage conditions, different incubation temperature, and also the effects of different chemicals such as EDTA, EGTA, and complement binding factors.

Fig.1 Rohu serum and 1\% (v/v) sheep red blood cells (SRBCs) were incubated at different temperatures $\left(10,20,30\right.$ and $\left.37^{\circ} \mathrm{C}\right)$. The results are expressed as a mean value $( \pm \mathrm{SE})$. Pooled serum (10 fish, $\mathrm{n}=10$ ) was used for the determination of $\mathrm{SH} 50 \%$ assay

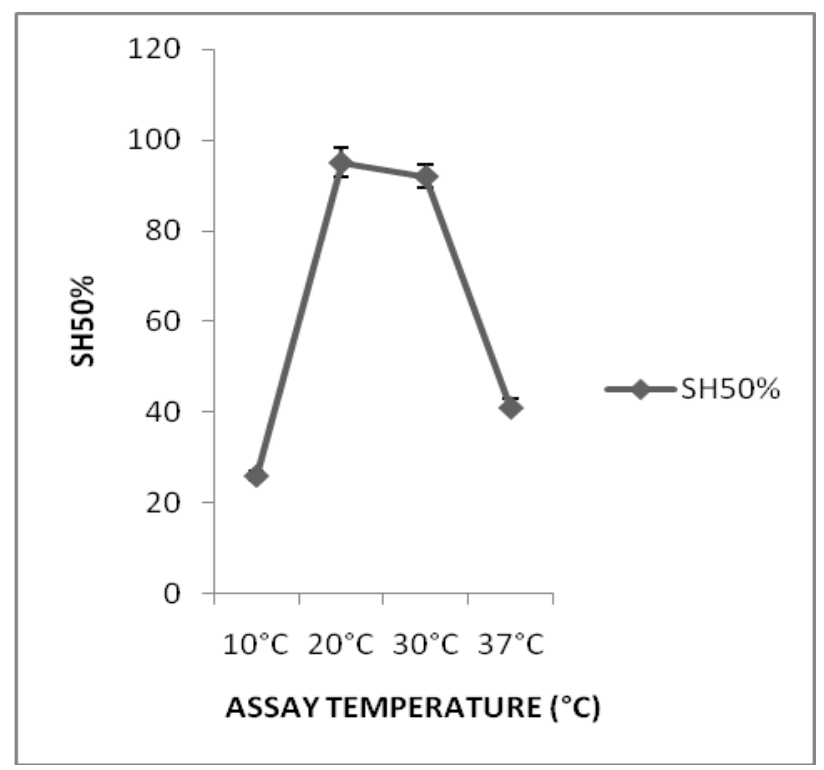

Fig.2 Determination of SH50\% for rohu sera with different RBCs donors at $28{ }^{\circ} \mathrm{C}$. The results are expressed as a mean value $( \pm \mathrm{SE})$. X-axis represents different $\mathrm{RBC}$ donors. Small letters above the bars indicates statistical significant $(\mathrm{P}<0.05)$ differences between $\mathrm{RBC}$ donors

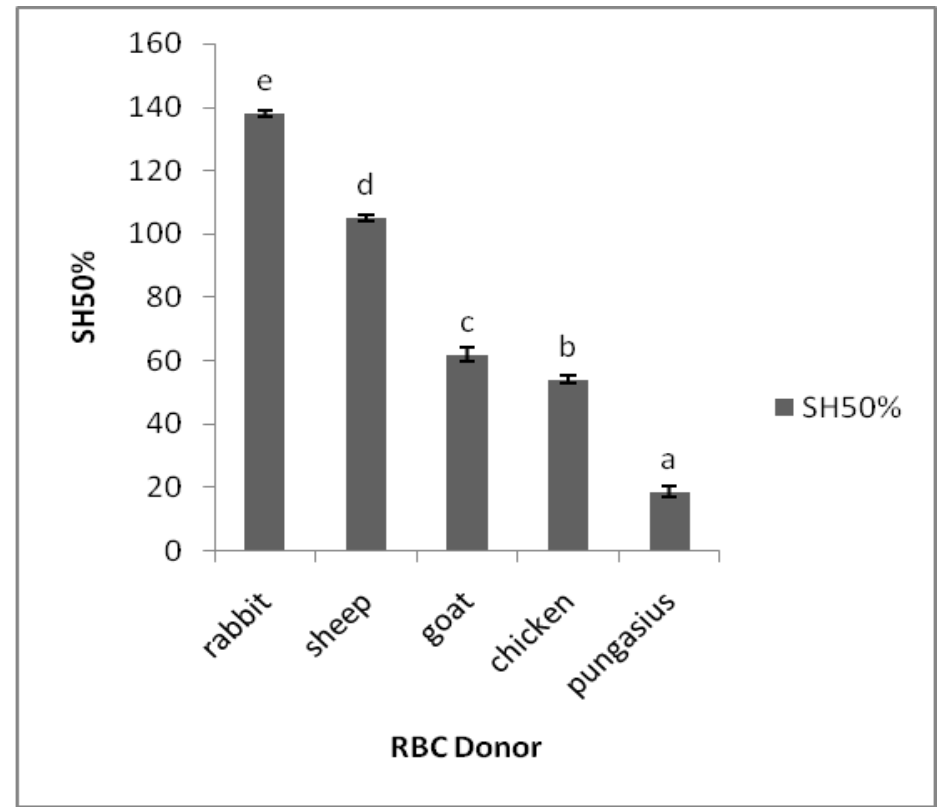


Fig.3 The ability of eight different rohu serum to lyse rabbit RBCs. The eight individual rohu serum from different fish of same size were assessed for the ability to lyse rabbit RBCs (1\% v/v) at $28{ }^{\circ} \mathrm{C}$. X-axis represents eight individual rohu serum. Small letters above the bars indicates statistical significant $(\mathrm{P}<0.05)$ differences between individual serum

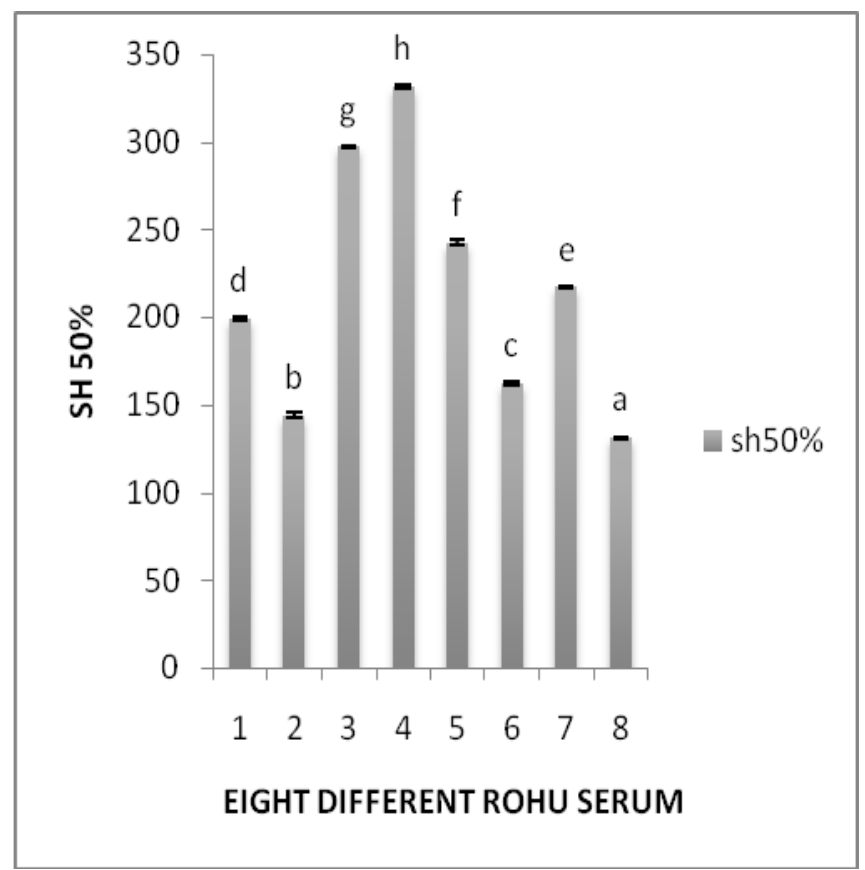

Fig.4 Rohu sera was inactivated at different temperatures $\left(18,27,45,56\right.$, and $\left.65^{\circ} \mathrm{C}\right)$ for $30 \mathrm{~min}$. Results are represented as mean value $( \pm \mathrm{SE})$

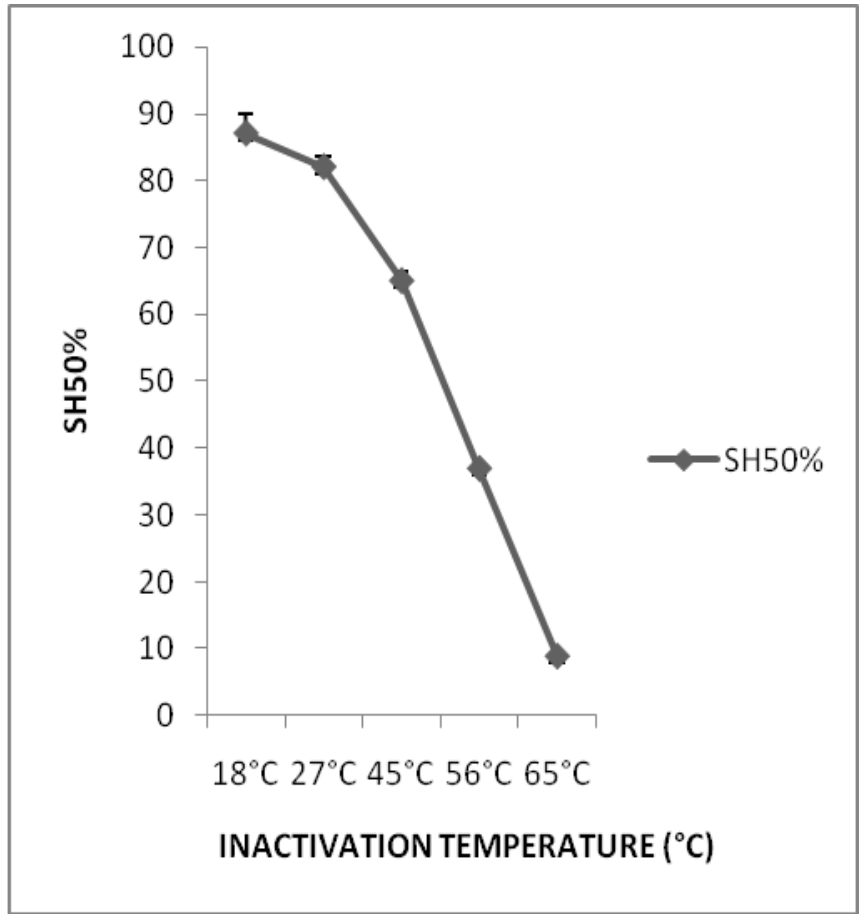


Fig.5 The effect of various concentrations of EDTA on SH50\% activity. Rohu serum (pooled from 10 fish) was treated with different concentrations of EDTA, starting from $0 \mathrm{mM}$ (untreated serum) to $5 \mathrm{mM}$ EDTA concentration. Small letters above the bars indicates statistical significant $(\mathrm{P}<0.05)$ differences between EDTA treated serum

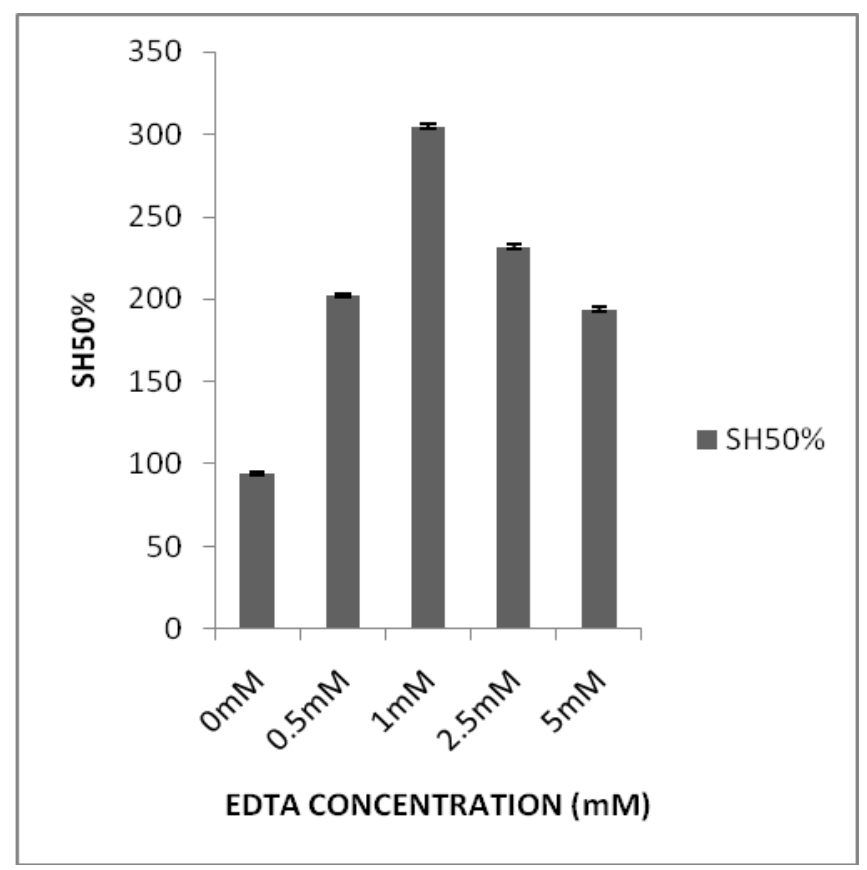

Fig.6 The effect of complement binding factors and A. hydrophila on the haemolytic activity of rohu sera. The complement binding factors (zymosan and LPS) and the A. hydrophila was incubated with pooled rohu sea (10 fish) and SH\% was determined. Results are means $\pm \mathrm{SE}, \mathrm{n}=$ 10 fish. Significant difference ( $p<0.05$ using a Student's t-test to compare control group and treated group)

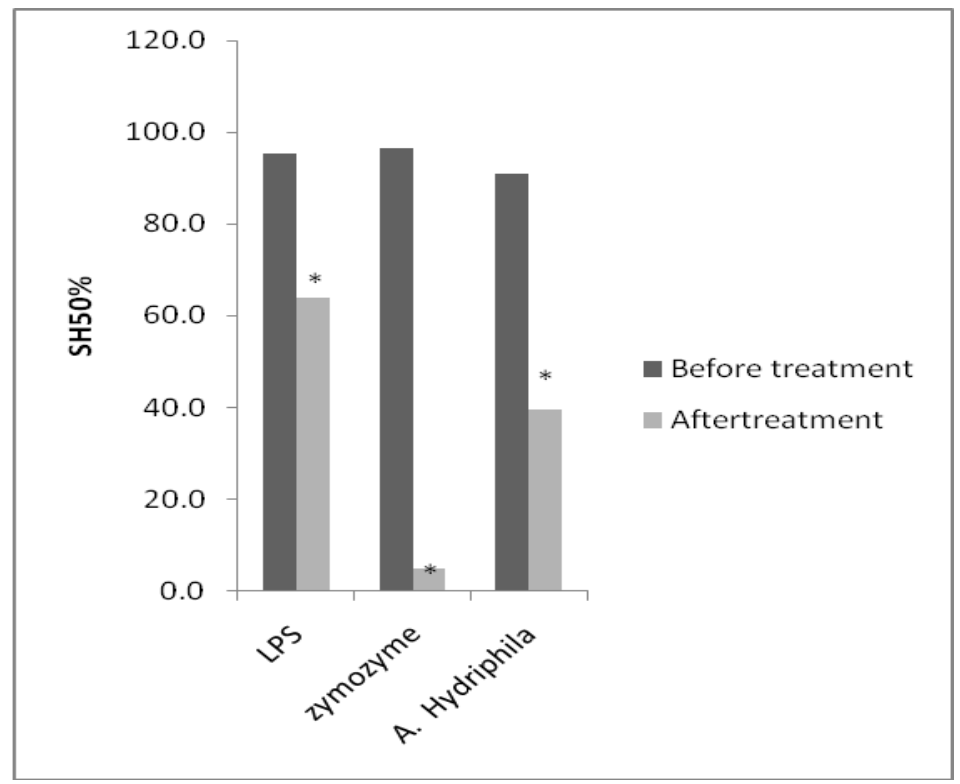


Fig.7 The effect of storage and freezing on the haemolytic activity. Rohu sera was stored at different storage temperature and time combination $\left(4^{\circ} \mathrm{C}\right.$ for 1 week, $-80{ }^{\circ} \mathrm{C}$ for 3 weeks, $-80{ }^{\circ} \mathrm{C}$ for 5 mints and $-20{ }^{\circ} \mathrm{C}$ for 1 year) and $\mathrm{SH} \%$ was determined. $\mathrm{C}$ represents control, the fresh serum was for $\mathrm{SH} \%$ calculation

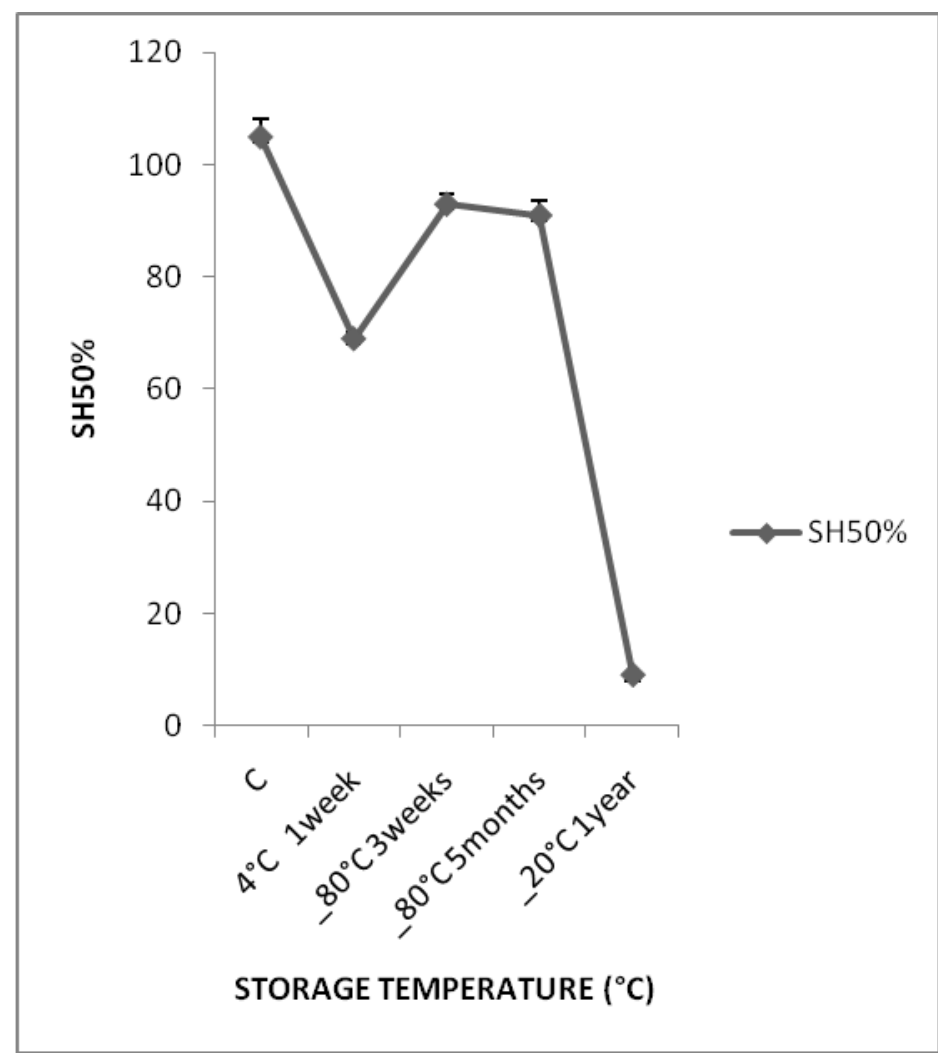

Table.1 The effect of complement binding factors on the haemolytic activity of rohu sera

\begin{tabular}{|c|c|c|}
\hline Treatment & Mean SH50\% & S.E. \\
\hline CONTROL & 94 & 1.15 \\
\hline EGTA (1mM) & 56 & 2.34 \\
\hline EDTA $(\mathbf{1 m M})$ & 304 & 1.45 \\
\hline
\end{tabular}

The optimum temperature of rohu sera for carrying out $\mathrm{SH}$ activity was determined as $20^{\circ} \mathrm{C}$. This finding is in line with the earlier studies on seabass and halibut (Lange and Magnadottir, 2003) where they had reported that the optimum assay temperature of $22^{\circ} \mathrm{C}$ in seabasssera and $16^{\circ} \mathrm{C}$ for halibut sera.

From these findings it may be concluded that the spontaneous haemolytic activity of normal fish sera varies depending on species.
The various RBCs donor animals used in our study were sheep, goat, rabbit, chicken and Pangasius fish. The SH activity of rohu sera was found to be maximum with rabbit RBCs and was minimum with Pangasius fish. From the above finding it is evident that the rohu serum showed more sensitivity to rabbit RBCs. Earlier studies has shown divergent view on this. The Seabass (Dicentrarchuslabrax) sera showed the highest SH activity with rabbit RBCs while 
halibut sera showed more activity to sheep RBCs (Lange and Magnadottir, 2003). Moreover, it has been manifested from earlier studies that, rabbit RBCs was one of the best sensitizer of fish complement system (Sunyer and Tort, 1995; Magnadottir, 2000). The reason for the less SH activity of rohu serum with Pangasius fish RBCs was may be due to closer phylogenetic relationship between the two species and distant relationship between the fish and mammalian or avian species.

The SH activity of rohu serum showed reduced activity after incubation at higher temperatures. The diminished $\mathrm{SH}$ activity at $56{ }^{\circ} \mathrm{C}$ and $65^{\circ} \mathrm{C}$ indicated that heating results in inactivation of fish serum. However, there was less reduction in SH activity when incubated at $18{ }^{\circ} \mathrm{C}$ for $30 \mathrm{~min}$, as evident from earlier studies, in sea bass and halibut sera (Lange and Magnadottir, 2003), and in seabream sera (Sunyer and Tort, 1995).

EDTA capable of inhibiting both alternative and classical complement pathway as it binds with both $\mathrm{Ca}^{2+}$ and $\mathrm{Mg}^{2+}$.In the present study, the less and more concentrations of EDTA increased the SH activity of rohu sera, when EDTA supplemented buffer was used for carrying out the $\mathrm{SH}$ test. The addition of EDTA has resulted in unusual increase of $\mathrm{SH}$ activity; this may be due to the increase in the ionic strength of buffer. Earlier study supported our findings, (Magnadottir, 2000) was in cod (Gadus morhua) serum, there was also unusual increase in $\mathrm{SH}$ activity when assay was carried out with EDTA supplemented buffer. Some of the earlier studies contradicts our results, for example, Lange and Magnadottir, (2003) found that when EDTA $(1 \mathrm{mM}$ and $10 \mathrm{mM}$ concentration) supplemented buffer was used for determining $\mathrm{SH}$ assay, at these two concentrations of EDTA there was decrease in SH activity.
EGTA capable of inhibiting classical complement pathway as it binds with $\mathrm{Ca}^{2+}$. In the present study, when EGTA supplemented buffer was used it led to slight reduction in the SH activity. However, previous studies showed conflicting effects on this. EGTA supplementation has resulted in inhibition effect on SH activity of seabass (Dicentrarchuslabrax) and halibut (Hippoglossus hippoglossus) sera (Lange and Magnadottir, 2003), whereas, there was no effect of the EGTA on SH activity of cod sera (Magnadottir, 2000).

The complement binding factors such as zymosan (fungal product) and LPS (bacterial cell wall component) has led to decrease in the SH activity of rohu sera. Treatment with zymosan reduced the $\mathrm{SH}$ activity to a great extent whereas the LPS reduced the SH activity to less extent. It has been reported from earlier studies that the fungal and bacterial product are capable of activating fish and mammalian complement system (Sakai, 1983). Some of the previous reports by (Sakai, 1983, Sunyer and Tort, 1995; Magnadottir, 2000, Lange and Magnadottir, 2003) narrated that there is reduction of $\mathrm{SH}$ activity of normal serum upon treatment zymosan and LPS.

The rohu sera showed reduction in $\mathrm{SH}$ activity when incubated with fresh culture of A. hydrophila indicating presence of the LPS on the cell wall of bacteria. In the similar manner, it has been established from previous study that the bacterial preparation had reduced the SH activity of cod sera (Magnadottir, 2000). Furthermore, the present study also noticed the variations in haemolytic activity of sera among eight individual fish sera tested for this fish species. Similar characteristics have also been described in earlier studies on cod sera and on Atlantic halibut and sea bass sera (Magnadottir, 2000; Lange and Magnadottir, 
2003). Such variation SH activity in individual fish may be due to unavoidable handling stress during drawing of blood from fish.

It can concluded from the present study that the mechanisms of serum complement activities for various fish species studied so far are differ in some features and almost same for other features. The present study depicts the species specific characteristics features of the complement components participating in the $\mathrm{SH}$ activity in fish blood serum and the data signifies the involvement of the complement system to immunological activities of this species. Catlare present one of the important cultured Indian major carps that have good contribution for freshwater aquaculture production. The serumcomplement system could be an important innate immune component which provide protection by attack of pathogens, and could be one of the reasons for better health conditions.

\section{Acknowledgments}

The authors extends gratitude to Director/Vice chancellor, Central Institute of Fisheries Education (CIFE), Mumbai, for providing the necessary facilities to carry out this research work and also thankful to the Indian Council of Agricultural Research (ICAR), New Delhi for the financial support.

\section{References}

Akira S, Uematsu S, Takeuchi O. 2006. Pathogen recognition and innate immunity. Cell, 124: 783-801.

Alexander, J. B, Ingram, G. A. 1992. Noncellular nonspecific defence mechanisms of fish. Annual Review of Fish Diseases, 2: 249279.

Anderson, D. P. 1992. Immunostimulants, adjuvants, and vaccine carriers in fish: applications to aquaculture. Annual Review of Fish Diseases, 2: 281-307.

Boesen, H. T., Pedersen, K., Larsen, J. L., Koch, C., Ellis, A. E. 1999. Vibrio anguillarum resistance to rainbow trout (Oncorhynchus mykiss) serum: role of $\mathrm{O}$-antigen structure of lipopolysaccharide. Infectious Immunity, 67: 294-301.

Ellis, A. E. 2001. Innate host defense mechanisms of fish against viruses and bacteria. Development and Comparative Immunology, 25: 827-39.

Farries, T. C. and Atkinson, J. P. 1991. Evolution of the complement system. Immunology Today, 12: 295-300.

Fock, W. L., Chen, C. L., Lam, T. J., Sin, Y. M. 2001. Roles of endogenous serum lectin in the immune protection of blue gourami, Trichogaster trichopterus (Pallus) against Aeromonas hydrophila. Fish and Shellfish Immunology, 11: 101-13.

Guardiolaa, F.A., Miguel Saraiva-Fraga M., Cuestab, M. A., Esteban, M. A. 2018. Changes in natural haemolytic complement activity induced by stress in gilthead seabream (Sparus aurata L.). Fish and Shellfish Immunology, 78: 317-321

Holland, M. C. H., Lambris, J. D. 2002. The complement system of teleosts. Fish and Shellfish Immunology, 12: 399-420.

Lange, S., Gudmundsdottir, B. K., Magnadottir, B. 2001. Humoral immune parameters of cultured Atlantic halibut (Hippoglossus hippoglossus L.). Fish and Shellfish Immunology, 11: 523-535.

Lange, S., Magnadottir, B. 2003. Spontaneous haemolytic activity of Atlantic halibut (Hippoglossus hippoglossus L.) and sea bass (Dicentra rchuslabrax) serum. Comparative biochemistry and Physiology Part B, 136: 99-106.

Magnadottir, B. 2006. Innate immunity of fish (overview). Fish \& Shellfish Immunology, 20: $137-51$.

Magnadottir, M. 2000. The spontaneous haemolytic activity of cod serum: heat insensitivity and other characteristics. Fish and Shellfish Immunology, 10: 731-735.

Miller-Eberhard, H. J. 1988. Molecular organization and function of the complement system. Annual Review of Biochemistry, 57: 32 1-347. 
Nakao, M., Mutsuro, J., Nakahara, M., Kato, Y., Yano, T. 2003. Expansion of genes encoding complement components in bony fish: biological implications of the complement diversity. Development and Comparative Immunology, 27: 749-762.

Nikoskelainen, S., Bylund, G., Lilius, E.M. 2004. Effect of environmental temperature on rainbow trout (Oncorhynchus mykiss) innate immunity. Development and Comparative Immunology, 28: 581-92.

Nikoskelainen, S., Lehtinen, J., Lilius, E. M. 2002.Bacteriolytic activity of rainbow trout (Oncorhynchus mykiss) complement. Development and Comparative Immunology, 26: 797-804.

Ortuno, J., Cuesta, A., Esteban, M. A., Meseguer, J. 2001a. Effect of oral administration of high vitamin $\mathrm{C}$ and $\mathrm{E}$ dosages on the giltheadseabream (Sparusaurata L.) innate immune system.Veterinary Immunology and Immunopathology, 79: 167-80.

Ortuno, J., Esteban, M. A., Messeguer, J. 2001b. Effects of short-term crowding stress on gilthead seabream (Sparus aurata L.) innate immune response. Fish and Shellfish Immunology, 11: 187-97.

Pushpa, K., Gireesh-Babu, P., Rajendran, K. V., Purushothaman, C. S., Dasgupta, S., Makesh, M. 2014. Molecular cloning, sequencing and tissue-level expression of complement C3 of Labeorohita (Hamilton, 1822). Fish and Shellfish Immunology, 40: 319-330

Sakai, D. K. 1983. The activation of alternative pathway by pronase, LPS and Zymosan in the complement system of rainbow trout serum.Bulletin of the Japanese Society for the Science of Fish, 49: 347-351.

Sakai, D. K. 1992. Repertoire of complement in immunological defence mechanisms of fish. Annual Review of Fish Diseases, 2:223-
247.

Sakai, M. 1999. Current research status of fish immunostimulants. Aquaculture, 172: 6392.

Salte, R., Gjoen, H. M., Norberg, K. Gjedrem, T. 1993. Plasma protein levels as potential marker traits for resistance to furunculosis. Journal of Fish Diseases, 16: 561-8.

Sunyer, J. O. and Lambris, J. D. 1998. Evolution and diversity of the complement system of poikilothermic vertebrates. Immunological Reviews, 166: 39-57.

Sunyer, J. O., Tort, L. 1995. Natural haemolytic and bactericidal activities of sea bream (Sparusaurata) are affected by the alternative complement pathway. Veterinary Immunology and Immunopathology, 45: 333-345.

Tahir, A., Fletcher. T. C., Houlihan, D. F., Secombes, C. J. 1993. Effect of short-term exposure to oil-contaminated sediments on the immuneresponse of dab (Limandalimanda L). Aquatic Toxicology, 27: 71-82.

Uribe, C., Folch, H., Enriquez, R. and Moran, G. 2011. Innate and adaptive immunity in teleost fish: a review. Veterinary Medicine, 56(10): 486-503.

Whyte, S. K. 2007. The innate immune response of finfish - A review of current knowledge. Fish and Shellfish Immunoogy, 23: 11271151.

Wu Y., Gong Q., Fang, H., Liang, W., Chen M., He, R (2013).Effect of Sophoraflavescens on non-specific immune response of tilapia (GIFT Oreochromis niloticus) and disease resistance against Streptococcus agalactiae. Fish and Shellfish Immunology, 34(1): 220227

\section{How to cite this article:}

Pushpa Choudhary and Makesh, M. 2019. The Spontaneous Haemolytic Activity of Catla catla Blood Serum Represents the Characteristics Features. Int.J.Curr.Microbiol.App.Sci. 8(08): 1945-1956. doi: https://doi.org/10.20546/ijcmas.2019.808.229 